\title{
Housing Finance Imperfections, Taxation, and Private Saving: A Comparative Simulation Analysis of the United States and Japan*
}

\author{
FUMIO HAYASHI \\ University of Pennsylvania, Philadelphia, Pennsylvania 19104; and National Bureau of \\ Economic Research, Cambridge, Massachusetts 02138 \\ TAKatoshi ITo \\ University of Minnesota, Minneapolis, Minnesota 55455; and National Bureau of \\ Economic Research, Cambridge, Massachusetts 02138
}

\begin{abstract}
AND
Joel SLemrod

University of Michigan, Ann Arbor, Michigan 48109; and National Bureau of Economic Research, Cambridge, Massachusetts 02138
\end{abstract}

Received June 1, 1987

\begin{abstract}
Hayashi, Fumio, Ito, Takatoshi, and Slemrod, Joel-Housing Finance Impefections, Taxation, and Private Saving: A Comparative Simulation Analysis of the United States and Japan

This paper presents a life-cycle simulation analysis of the interaction among savings decisions, housing purchase decisions, and the tax system in the United States and Japan. To investigate this issue, we first document the stylized fact that the typical Japanese household purchases a house later in the life cycle with a higher down-payment ratio than its U.S. counterpart. Second, a life-cycle simula-
\end{abstract}

\footnotetext{
* Financial support from a Sloan Foundation grant on transactions costs administered by the University of Minnesota is gratefully acknowledged. This work was initiated when Fumio Hayashi was visiting at the Department of Economics, University of Minnesota. We thank the Ministry of Construction, Japan, for supplying us with data. Comments on previous versions by Patric Hendershott, Tsuneo Ishikawa, Joyce Manchester, David Wise, Naoyuki Yoshino participants of a seminar at the Ministry of Finance, Japan, and anonymous referees were very helpful.
} 
tion model that includes the housing purchase decision is constructed and used to compare the behavior of typical U.S. and Japanese households. The Japanese household is induced to save more early in the life cycle in order to meet the higher down-payment requirement. However, the contribution of the induced early saving due to the down-payment requirement seems to be too small to explain a large differential in the saving rates of the two countries. The high economic growth of the late 1950s and 1960s in Japan is instrumental in explaining its high saving rate. Finally, tax reform concerning the tax deductibility of mortgage interest payments or the tax-exempt status of interest income is shown to have a small impact on the aggregate saving rate in either country. For example, the introduction of tax-exempt saving in the United States would increase the saving rate by only $1.5 \%$. J. Japan. Int. Econ., September 1988, 2(3), pp. 215238. University of Pennsylvania, Philadelphia, Pennsylvania 19104, and National Bureau of Economic Research, Cambridge, Massachusetts 02138; University of Minnesota, Minneapolis, Minnesota 55455, and National Bureau of Economic Research, Cambridge, Massachusetts 02138; and University of Michigan, Ann Arbor, Michigan 48104, and National Bureau of Economic Research, Cambridge, Massachusetts 02138. 1988 Academic Press. Inc.

Journal of Economic Literature Classification Numbers 023, 315.

\section{INTRODUCTION}

It is widely noted that one of the major differences between the U.S. and Japanese economies is found in the institutions and regulations of financial markets. In addition, the tax incentives for saving and borrowing in the two countries are quite different. Most of the interest income from consumer savings is tax exempt and interest payments of consumer mortgages and debts are not tax deductible in Japan, while the opposite is true in the United States. ${ }^{1}$ Institutional arrangements concerning housing, one of the major expenditure items in a lifetime for most consumers, are also quite different in the two countries. Many economists have suggested that

'In Japan, interest income from the following savings (with a ceiling on principal amounts) was tax exempt prior to April 1, 1988: (i) regular postal saving up to 3 million yen; (ii) postal saving earmarked for housing purchase up to 0.5 million yen; (iii) "Maru-yu," that is, any deposits in bank securities and mutual funds, up to 3 million yen; (iv) "special maruyu," that is, government and municipal bonds, new issues and secondary, up to 5 years after issue, up to 3 million yen; and (v) only for employees of age 54 or younger, for the purpose of accumulating assets for housing and retirement funds, up to 5 million yen. Thus a young employee who wants to save for a housing purchase can receive tax-free interest up to 14.5 million yen $(\$ 90,625$, if $\$ 1=160$ yen). Even beyond the tax exempt ceiling, there are financial instruments (discount bonds issued by investment banks and governments) which are subject to a low tax rate (16\%) regardless of the income tax bracket of the bondholder. About 58\% of personal savings is in one of the above forms of tax-exempt savings (Bank of Japan, 1986; p.158). As of April 1, 1988, tax exemptions for types (i) and (iii) are replaced by a $20 \%$ interest income tax. Tax-exempt "new maru-yu" accounts can be held by the elderly (65 years or older), the handicapped, or single mothers. 
differences in housing financing between the two countries may be partially responsible for the large gap in the personal saving rate between the two countries. (See Hayashi (1986) for a survey of the literature.) In a world with perfect capital markets where a consumer can borrow and lend over his life cycle, whether a consumer decides to rent housing or purchase a house would not have any effect on the lifetime consumptionsaving pattern. However, in the presence of a liquidity constraint (i.e., a down-payment requirement) purchasing a house may create a distortion in the lifetime consumption-saving decision. A higher down-payment requirement may induce households to postpone consumption early in the life cycle in order to build up enough assets to qualify for buying a house.

The goal of this paper is to investigate the effect of tax incentives and down-payment requirements on households' tenure choice (own or rent) concerning housing and on consumption-saving patterns, with a comparison of the United States and Japan in mind. In particular, a life-cycle simulation model will be constructed to quantify the effect of these policies on the personal saving rate. The methodology is based on that of Slemrod (1982), who constructed a life-cycle model with endogenous homeownership decisions. ${ }^{2}$ He showed that although the favorable tax treatment of owner-occupied housing in the United States encourages an early purchase of housing, the down-payment constraint induces the consumer to delay the purchase to avoid distortion in the consumptionsaving pattern. Thus, an optimal lifetime pattern of tenure choice of housing is determined as a trade-off between the tax incentives and the required distortions in the lifetime consumption stream.

In this paper, we apply an expanded version of the Slemrod model to a comparative study of the U.S. and Japanese housing markets. The model predicts that due to the imperfect capital market, transaction costs, and the relatively higher housing price, the Japanese are induced to save more toward the down payment and to acquire a home later in their life cycle.

Reasonable values are substituted from the stylized facts of the two countries. Most parameter values in the simulation model are based on observed data of the U.S. and Japanese economies. Some parameter values are chosen so that the tenure pattern and saving rates that our model predicts are matched with the observed tenure pattern in each country.

${ }^{2}$ As in Slemrod's model, land, a nonreproducible asset, is not explicitly introduced in our model. The value of land relative to total household wealth is much higher in Japan than in the United States. Morever, land has presumably appreciated more than financial wealth. The potentially important role of land in the saving process and its implications for the differential performances of the United States and Japan are not explored in this paper. One simplification adopted in the paper is that the model considers only the demand side of the asset. The supply of housing is not modeled and the general equilibrium response of prices to changes in policies is not included in the analysis. 
Exercises with the simulation model are developed to show how much the difference in tax incentives contributes to the savings rate gap between the two countries. It is particularly interesting to investigate how tax reform would affect the aggregate saving rate and housing tenure choice, since reforms have been implemented or proposed recently in both countries. On April 1, 1988, Japan abolished most of the tax exemption for saving and replaced it with a uniform low tax rate. Furthermore, a tax break for the purchase of owner-occupied housing, in one form or another, has been proposed in Japan. In the United States, incentives for saving have been introduced in the form of the all-savers' certificate and individual retirement accounts, although these programs have been cut back recently. In addition, some recent tax reform proposals, in particular flat tax proposals, feature the elimination of the tax deductibility of home mortgage interest payments.

In the discussion of tax reform in either country, no one has presented quantitative estimates showing how much the house tenure pattern and the saving rate would change due to the proposed reform. This paper will take up this task using a simulation model.

In Section 2, we describe a life-cycle model with endogenous housing tenure choice which is a special case of Slemrod's (1982) model. Sections 3 and 4, respectively, summarize the stylized facts of the U.S. and Japanese housing markets. Section 5 presents the results of various exercises using the simulation model to investigate the effect of changes in the economic environment in both countries. Section 6 offers some concluding remarks.

\section{A Life-cycle Model with Housing Tenure Choice}

In this section, we describe a six-period life-cycle model which will be used for the simulation analyses to be discussed later. Each period is meant to represent $\mathbf{1 0}$ years of a person's adult lifetime. The household, which lives six periods, chooses the consumption of a composite commodity and housing services for each period over the lifetime. Housing services may be obtained either by purchasing a house or by renting housing. Imperfect capital markets are assumed in that the household cannot borrow to finance nonhousing consumption. The household can, however, obtain a mortgage toward purchase of a house, provided it can come up with a down payment which is some fraction of the house value. The liquidity constraint may be binding for two reasons. First, when income early in the life cycle is less than income later, as will be assumed, consumption smoothing may become impossible. Second, if owner-occupying as opposed to renting is preferred, the household has to save in 
order to accumulate enough wealth for the down payment. Even if the liquidity constraint for consumption smoothing is binding, there may be positive saving in order to build up the down payment.

The desirability of owning a house comes from two sources. First, it is assumed that a house owned would yield services with higher utility than the identical house if rented. This assumption is meant to represent the advantage of eliminating the principal-agent relationship if one rents from oneself; i.e., a renter cannot alter, paint, and improve a house as desired, and a renter is subject to a risk of termination of lease or rent increase in the future. Second, in the United States, the imputed income from owneroccupied housing is untaxed, while interest payments are tax deductible and interest income from saving is taxable. This feature makes owning a house more attractive than renting one, unless there are offsetting tax advantages offered to landlords. This argument does not apply identically to Japan, where interest payments are not tax deductible and most of personal interest income is (until recently) practically tax exempt. To the extent that rental income is taxed, however, there is a tax-related advantage to owning housing as opposed to renting in Japan as well as in the United States.

It is assumed that in the first period the household cannot purchase a house because of the liquidity and down-payment constraints. Likewise, by the beginning of the last period, the household must sell any owned housing and move into a rental unit, consuming all the proceeds of the house sale in the last period. (We abstract from the bequest motive until later.) Thus the household has a choice of owning a house during any of the second, third, fourth, and fifth periods, but can buy only once. For each own/rent lifetime pattern, the household can calculate the optimal consumption/saving pattern by maximizing the discounted sum of lifetime utility subject to the lifetime budget constraint and the liquidity and downpayment constraints. By comparing the maximized levels of lifetime utility for different patterns of tenure choice, the household picks the own/ rent pattern that yields the highest utility. (For simplicity, depreciation on a house is ignored.)

We assume housing purchases and sales take place at the end of a period. When a house is purchased with a down payment $d$ of the house value, the down-payment expenditure is deducted from income of the period of house purchase. The mortgage debt $(1-d)$ becomes $(1+R)$ $(1-d)$ at the beginning of the next period, where $R$ is the (before tax) interest rate. An equal payment of $V$ for $m$ periods amortizes the mortgage debt. (Later, $m=2$ for Japan and $m=3$ for the United States will be chosen.) The interest portion of the mortgage repayment is tax deductible in the United States. Thus the "net" mortgage repayment $V(m)$ in the United States is the mortgage payment less the (deductible) interest por- 
tion of the repayment for the $m$ th installment. When a house is sold, the value of the house, less remaining mortgage, is used for consumption after the period of the sale.

The instantaneous utility function is assumed to be log linear in consumption and housing services (with weight $\alpha$ ), and lifetime utility is assumed to be additively separable over time. For example, suppose that household purchases a house at period $t(b)$ and sells at period $t(s)$. The household has to solve the following problem: Maximize with respect to $t(b), t(s),\{c(t), t=1, \ldots, 6\},\{h(t), t=1, \ldots, t(b), t(s)+1, \ldots, 6\}$, $H$,

$$
\begin{aligned}
\left.\sum_{t=1}^{t(b)} \beta^{t-1}\{\log c(t)+\alpha \log h(t)\}+\sum_{t=t(b)+1}^{t(s)} \beta^{t-1}\{\log c(t)+\alpha \log \gamma H)\right\} & \\
& +\sum_{t=t(s)+1}^{6} \beta^{t-1}\{\log c(t)+\alpha \log h(t)\}
\end{aligned}
$$

subject to $A(0)=0$,

$$
\begin{aligned}
& A(t)=(1+R(1-\tau)) A(t-1)+y(t)-c(t)-P_{\mathrm{r}} P_{\mathrm{h}} h(t), \\
& t=1, \ldots, t(b)-1 \\
& A(t)=(1+R(1-\tau)) A(t-1)+y(t)-c(t)-P_{\mathrm{r}} P_{\mathrm{h}} h(t)-d P_{\mathrm{h}} H, \\
& t=t(b) \\
& A(t)=(1+R(1-\tau)) A(t-1)+y(t)-c(t)-V(m)(1-d) P_{\mathrm{h}} H, \\
& t=t(b)+1, \ldots, t(s)-1 \\
& A(t)=(1+R(1-\tau)) A(t-1)+y(t)-c(t)-V(m)(1-d) P_{\mathrm{h}} H+P_{\mathrm{h}} H, \\
& t=t(s) \\
& A(t)=(1+R(1-\tau)) A(t-1)+y(t)-c(t)-P_{\mathrm{r}} P_{\mathrm{h}} h(t), \\
& t=t(s)+1, \ldots, 6 \\
& A(t) \geq \max \left[0, d P_{\mathrm{h}} H+\sum_{m-1}^{t-t(b)}\{V-(V-V(m)) / \tau\}\right]
\end{aligned}
$$

[liquidity constraint], $t=1, \ldots, 5$

$A(6)=0$

[no bequest condition],

where $y(t)$ and $c(t)$ are labor income and consumption in period $t$, respectively; $A(t)$ is the end-of-the-period financial asset value; $h$ is the size of a 
rental unit (which could vary every period); $H$ is the size of an owneroccupied unit (which remains constant once purchased); $R$ is the interest rate on financial assets and liabilities; $P_{r}$ is the price per period of a rental unit; $P_{h}$ is the price of the owner-occupied house; $\gamma, \tau, d$ are parameters representing the pride-of-ownership coefficient, the tax rate on income from saving and financial assets, and the required down-payment ratio, respectively. We define the unit of $H$ such that $\boldsymbol{P}_{\mathrm{h}}$ can be normalized to one. Under the assumption of a Cobb-Douglas utility function, $H$ has a unit price elasticity. Therefore, the normalization does not affect the qualitative results in this paper.

There is an implicit arbitrage condition assumed between rental property investment and financial asset investment. $P_{\mathrm{r}}$ equals $R$ due to arbitrage between the financial asset and real asset if both incomes are taxable, as in the United States. $P_{\mathrm{r}}$ equals $R\left(1-\tau^{\mathrm{r}}\right)$ if interest income on financial assets is not taxed but rental income is taxed, as in Japan, where $\tau^{\mathrm{r}}$ is the tax rate on rental income. Saving in this model is defined as the change in total wealth.

The liquidity constraint implies that total borrowing must be less than or equal to the value of owned housing. The calculation of $V(m)$ needs some explanation. For Japan, where there is no tax deductibility for interest payments, $V(m)=V$, and the equal installment is calculated from a condition that the mortgage be just paid up after the maturity of the mortgage. For the United States, $V(m)$ represents the equal payments of mortgage less the tax rebate resulting from tax deductibility of the mortgage interest payment. ${ }^{3}$

Due to the time separability and $\log$ linearity of the utility function, backward induction yields an explicit solution for optimal consumption, (rent/own) housing service for all periods.

${ }^{3}$ For Japan, suppose that the mortgage matures in two periods (20 years). The condition of equal payments is $(1+R)\{(1-d)(1+R)-V\}-V=0$. Solving this, we have

$$
\begin{array}{ll}
V(m)=V=(1-d)(1+R)^{2} /(2+R), & m=1,2 ; \\
V(m)=0, & m=3,
\end{array}
$$

In addition, interest income from saving is tax exempt, i.e., $\tau=0$. For the United States, suppose that the mortgage matures in three periods ( 30 years). The condition of equal payments is $(1+R)[(1+R)\{(1-d)(1+R)-V\}-V=0$. Solving this, we have $V=\{1-$ $d)(1+R)^{3 /\{}\left(1+(1+R)+(1+R)^{2}\right\}$. In the period of first installment, the interest portion of the mortgage payment is $(1-d) R$. Therefore multiplying the tax rate $\tau$, we obtain the amount of tax saving, $\tau(1-d) R$. The "net" mortgage payment is defined as $V(1)=V-(1-$ d)Rt. Since the principal balance is shrinking as the installment continues, the interest portion of the installment changes. Accordingly the net mortgage payment in the $m$ th installment is calculated as

$$
\begin{aligned}
& V(2)=V-\{(1-d)(1+R)-V\} R \tau \\
& V(3)=V-[(1+R)\{(1-d)(1+R)-V\}-V] R \tau .
\end{aligned}
$$


One extension of the model that we will consider is to include a bequest motive. In particular, we require that housing of value $q$ be left as a bequest. Assuming that the heirs are 30 years younger than the parents, the bequest is equally divided among the heirs who are at the end of their third period of life. Because population is larger and the lifetime income is higher for later generations, the size of the house per heir has to be adjusted accordingly, so that

$$
q_{\mathrm{h}}=q /\left\{((1+n)(1+g))^{3}\right\}
$$

where $q$ is the benefactor's house size, $q_{\mathrm{h}}$ is the heir's house size obtained at the end of the third period, $n$ is the population growth rate, and $g$ is the (generational) income growth rate.

\section{Characteristics of the U.S. Housing Market}

Data for mortgage financing with a government guarantee are available from the U.S. Department of Housing and Urban Development (HUD). In 1979, the average ratio of mortgage value to the value of a new onefamily house whose finance was government guaranteed was 0.921 . This ratio seems very high, partly due to a sample bias of government guarantees. The average loan-to-value ratio, $1-d$, of conventional mortgage financing, according to the Federal Home Loan Bank Board (1982), for a new home was 0.731 in 1980 and 0.748 in 1981. Based on these data, our first stylized fact is that the down-payment ratio is about 25 to $30 \%$ for conventional mortgages and only about $10 \%$ for housing with government loan guarantees. We select $25 \%$ as a benchmark of the U.S. downpayment ratio.

Second, the average age of mortgagor was about 30 for an owneroccupant transaction in 1980, according to the "FHA Trends of Home Mortgage Characteristics." Another source, the "Annual Housing Survey," confirms that among the cohort of household heads, 25-30 years old, more than $50 \%$ own a house rather than rent.

Third, the average maturity of a mortgage is about 30 years, according to HUD $(1979$, p. 295). Fourth, the house-value/annual-income ratio, $P_{\mathrm{h}} H / y(b)$, is 1.97 for a typical transaction of one-family housing, according to HUD $(1979$, p. 134). Last, the life-cycle income pattern of the U.S. household is calculated by multiplying the average income for an age bracket by the labor participation rate in 1980 . (Source: U.S. Department of Commerce, 1981; Department of Labor, 1985.) As a proportion of the average income of those 20-30 years old, the incomes of the six age 
brackets we are interested in are calculated as follows, after normalizing so that $y(1)+y(2)+\ldots+y(6)=1$ :

$$
\begin{aligned}
& y_{t}(1)=0.169 ; \quad y_{t}(2)=0.248 ; \quad y_{t}(3)=0.257 ; \\
& y_{t}(4)=0.218 ; \quad y_{t}(5)=0.108 ; \quad y_{t}(6)=0.000 \text {. }
\end{aligned}
$$

Since this income pattern with respect to age bracket is an observation at a point of time $t$, the lifetime pattern of a generation must be estimated in order to be used in the life-cycle maximization problem of one particular generation. In the steady state, this can be done by multiplying by the growth rate of (real) lifetime income over a generation. We assume that members of a generation receive $(1+g)$ as much income in every age bracket as members of a generation earlier so that

$$
y_{t+s}(k)=(1+g)^{s} y_{t}(k), \quad k=1,2, \ldots, 6 .
$$

The decade population (of those 15 years old and over) growth rate, $n$, is calculated as $20.04 \%$, the rate observed from 1970 to 1980 . The decade income growth rate over one generation (10 years apart), $g$, is fixed at $10 \% .^{4}$

\section{Stylized Facts in the Housing Markets in Japan}

\subsection{Loans vs Self-Financing ${ }^{5}$}

The ratio of down payment (literally translated as a ratio of self-financing) is defined as the ratio of the average amount the owner of a new home raised to the average cost of construction or purchase of the home. In the $1980 \mathrm{~s}$, the ratio of down payment has been about $40 \%$ for both custommade homes and homes purchased from developers. The rest, about $60 \%$ of purchase costs, comes from subsidized and privately financed loans.

However, there are two problems with using these figures. First, "down payment" in the Japanese survey is literally defined as "the portion of self-financing," including the owner's savings, gifts to the owner,

\footnotetext{
${ }^{4}$ There are various ways to approximate the decade income growth, depending on which income measures and which deflator is used. For example, the per capita real GNP. growth over the past 10 years less the population growth rate is about $10 \%$ of that of the United States.

${ }^{5}$ The facts are summarized from the survey study of the Ministry of Construction in Japan, conducted annually since 1974. (See Ministry of Construction, 1986.) The survey of 1985 covered about 10,000 individuals who ordered custom-made homes or bought homes from developers.
} 
and sales of other real assets. "Loans" in the survey refer to funds other than the owner's. If a new owner borrows without collateral some amount of money from his parents and applies it toward the "down payment" to the developer, the amount of money would still be counted as "loans" instead of "down payment." The ratio of "down payment" may therefore be biased downward. Although the exact division between "selffinance" and "loans" may not be comparable to the division into "down payment" and "mortgages" in the United States, this is the closest approximation possible and the direction of possible bias would not weaken our argument.

Second, the ratio of $40 \%$ is inclusive of second-time buyers who have trade-ins. If we take the down-payment ratio of the first-time buyers only, the down-payment ratio is about $35 \%$. In light of these facts, a plausible average for the down-payment ratio for the first-time buyer is about $35 \%$. This is our first stylized fact for the Japanese housing market.

\subsection{Average Age of New Owners}

The average age of the heads of households who built custom-made houses in 1985 is about 43.9 . However, if only first-time buyers are surveyed, the average age is about 40 .

This evidence is not quite sufficient for the purpose of our study of an own/rent tenure choice in the life-cycle context. Although it shows a distribution of ages of purchasers, it does not show in the cross section how many of the cohorts have previously owned houses. In order to overcome the difficulty, we consulted a source of representative crosssectional data in Japan, the "Family Saving Survey" collected by the Statistics Bureau of the Prime Minister's Office. The survey shows that the house ownership ratio (among the cohort) increases monotonically up to the age of 65 . At the age of $65,86.7 \%$ of heads of households own housing. It is between the ages of 35 and 39 when the majority of the cohort become homeowners. The ownership rate increases rapidly between the ages of 30 and 40 . From this we derive only the second stylized fact: In Japan, the average age of initial home purchase is about $\mathbf{4 0 .}$

However, looking at the percentage of households holding liabilities for purchase of houses and/or land, we note that less than $40 \%$ of households hold such liabilities. Investigating other statistics, we can conclude that more than one-third of house owners have no liabilities connected to housing. This is supporting evidence that liabilities due to home/land purchases are rather quickly paid up.

\subsection{Japanese Idiosyncrasies: Extended Families}

Care must be taken in comparing the Japanese housing market with its U.S. counterpart, in light of the prevalence of extended families. It is still 
common in Japan for young adults between the age of 18 and the time of marriage to live with their parents, if they live in the same town. The prevalence of this arrangement is partly due to the high relative cost of housing, both rental and owner-occupied, and partly due to social customs.

Even after their marriage, it is not uncommon for children to continue to live with their parents. This phenomenon appears in the above-mentioned survey concerning the question of what kind of housing the new owner had before. About $13 \%$ of owner construction and $6 \%$ of buyers used to "live together (with family)." This is a significant proportion, because as mentioned earlier the survey includes replacement and improvement demand for homes.

It is common in Japan that when parents become very old, or especially when one of them dies, the surviving parents are "looked after" by one of the children. A parent (or parents) might move into a house of one of the children, usually the eldest son; or the family of a child might move into the parents' house. In the former case, they lose the "head of household" status and become dependents in the household survey, thus dropping out of statistics using a classification by the age of head of households. In the latter case, in "return" for taking care of parents, it is usual, though not legally required, that the child who looks after the parents inherits the parent's home. (This is an extreme form of "strategic bequests," as advocated by Bernheim et al. (1985).) The parent(s) usually remains as the legal owner of the house. One reason for this arrangement is that for real estate, as opposed to financial securities, the inheritance tax is reduced since the assessed value for the inheritance tax is usually significantly less than the market value. In either case, it is rare that the elderly sell the home in order to move into a rental unit. These social and economic aspects of Japan partly explain why the ratio of homeowners among those 65 years old and over, among "heads of households," does not (seem to) decline.

To repeat, the second case implies that a typical Japanese family keeps an owner-occupied house, or even buys a new, larger home, after retirement. This is very much in contrast to the typical U.S. household that sells a big house after the children become adults. This aspect might not be adequately dealt with in a model based on the standard life-cycle theory, in particular Slemrod's life-cycle model of tenure choice.

Careful consideration of the bias caused by extended families in our study must be given. As for the effect of the living-in arrangement after the parents become old, there are two conflicting effects on the validity of our study. If the first case (parents moving into their children's home) is dominant, we do not have to worry about the comparability of the two countries, since an apparently high ownership ratio among the retired household heads is caused by selection bias (upward). In other words, in 
reality as opposed to the data, many sell their houses and live with a son's family or a daughter's family. Thus, the life-cycle framework of own/rent tenure choice still applies. However, if the second case (a son's or daughter's family moving into the parents' home) is dominant, then a bequest motive should be seriously modeled, and it may be the case that we have to argue that the difference in saving and houseownership between the United States and Japan is due to the extended family practice and a peculiar bequest motive in Japan. (See Hayashi (1986) for the extended family explanation of why the Japanese saving rate is so high.) Since we will not analyze the bequest motive in depth, we are implicitly assuming the second aspect of extended family relationship to be relatively insignificant. Further theoretical and empirical analysis is required to investigate how much the Japanese extended family relationship would affect housing tenure choice and saving decisions.

\subsection{Life-Cycle Labor Income Pattern and Price of Housing}

We need the life-cycle labor income pattern for the typical Japanese household for our simulation model. The method of calculation is the same as that used for the United States. The result is given in Hayashi (1986, Table 3):

$$
\begin{array}{lll}
y_{t}(1)=0.09 ; & y_{t}(2)=0.22 ; & y_{t}(3)=0.28 ; \\
y_{t}(4)=0.29 ; & y_{t}(5)=0.13 ; & y_{t}(6)=0.00 .
\end{array}
$$

The above number is the cross-section observation at time $t$ of the income pattern with respect to age brackets. As was discussed in the preceding section, the income pattern of a particular generation also depends on the growth rate of labor income over generations. The decade income growth rate, $g$, is approximated at $40 \% .6$ The population (age 15 and over) growth rate, $n$, is approximated at $13.05 \%$.

Last, in Japan, about a third of the price of housing services can be traced to land, which is scarce and expensive. The average housing-value/ annual-income ratio, $P_{\mathrm{h}} H / y(b)$, for buyers of a house with land (excluding those who rent land and who are given land by family and relatives), constructed from a survey done by Ministry of Construction (1982, p. 82), was 5.29.

\footnotetext{
- Again, the income growth rate can be approximated in several ways. For example, the growth rate of household disposable income less the CPI growth rate less the population (age 15 and over) growth rate from 1970 and 1980 would yield about $41 \%$, while the per capita real GNP growth rate is about $40 \%$.
} 


\section{Simulations}

\subsection{Benchmark}

In this section, the model presented in Section 2 is used as a simulation model with relevant parameter values derived from the observed facts summarized in Sections 3 and 4. Those parameters for a typical resident in each country are summarized in Table $I$.

First, we calculate the optimum housing tenure choice predicted by our simulation model. Given a rent-own pattern of housing for six periods, maximum lifetime utility is calculated by solving a dynamic problem of consumption (size of housing and consumption goods) and saving. The model then compares the maximized values of lifetime utility to decide the optimal pattern of tenure choice.

The model, as summarized for the benchmark case in Table II, predicts that the representative Japanese resident rents in periods 1, 2, and 6 of his life, and that the representative U.S. resident rents in periods 1 and 6 only. That is, the typical Japanese purchases a house when he is 40 years old with a 20-year mortgage and the typical American purchases a house

TABLE I

Benchmark Parameters

\begin{tabular}{lccccccccc}
\hline & \multicolumn{1}{c}{ Stylized facts $^{a}$} \\
& \multicolumn{1}{c}{} & & \multicolumn{1}{c}{} & \\
& $P_{\mathrm{h} H / y(b)}$ & $R$ & $\tau^{\mathrm{r}}$ & $\tau$ & $d$ & $\begin{array}{c}\text { Mortgage } \\
\text { maturity } \\
\text { (years) }\end{array}$ & $\begin{array}{c}\text { Aggregate } \\
\text { saving } \\
\text { rate (\%) }\end{array}$ & $\begin{array}{c}\text { Tenure } \\
\text { choice }^{b}\end{array}$ \\
\hline U.S. & 0.195 & 0.5 & 0.3 & 0.3 & 0.25 & 30 & 8.0 & ROOOO? \\
Japan & 0.529 & 0.5 & 0.3 & 0.0 & 0.35 & 20 & 18.29 & RROOO?
\end{tabular}

Stylized facts: Cross-section income pattern at period $t$

\begin{tabular}{lcccccccc} 
& $y_{r}(1)$ & $y_{r}(2)$ & $y_{r}(3)$ & $y_{r}(4)$ & $y_{r}(5)$ & $y_{r}(6)$ & $g$ & $n$ \\
\hline U.S. & 0.169 & 0.248 & 0.257 & 0.218 & 0.108 & 0.000 & 0.10 & 0.20 \\
Japan & 0.090 & 0.220 & 0.280 & 0.290 & 0.130 & 0.000 & 0.40 & 0.13
\end{tabular}

Benchmark parameter values: Assumptions

\begin{tabular}{cccll} 
& $\alpha$ & $\beta$ & \multicolumn{1}{c}{$P_{\mathrm{r}}$} & $\gamma$ \\
\hline U.S. & 0.15 & 0.75 & $R$ & 1.4 \\
Japan & 0.15 & 0.75 & $R\left(1-\tau^{\mathrm{r}}\right)$ & 1.4 \\
\hline
\end{tabular}

${ }^{a} \tau^{r}$ is the tax rate on rental income; $\tau$ is the tax rate on savings on financial assets; $R$ is the interest rate; $d$ is the down-payment ratio.

${ }^{b} \mathrm{R}=$ rent; $\mathrm{O}=$ own. 
TABLE II

Benchmark U.S.-JaPAN CoMParison

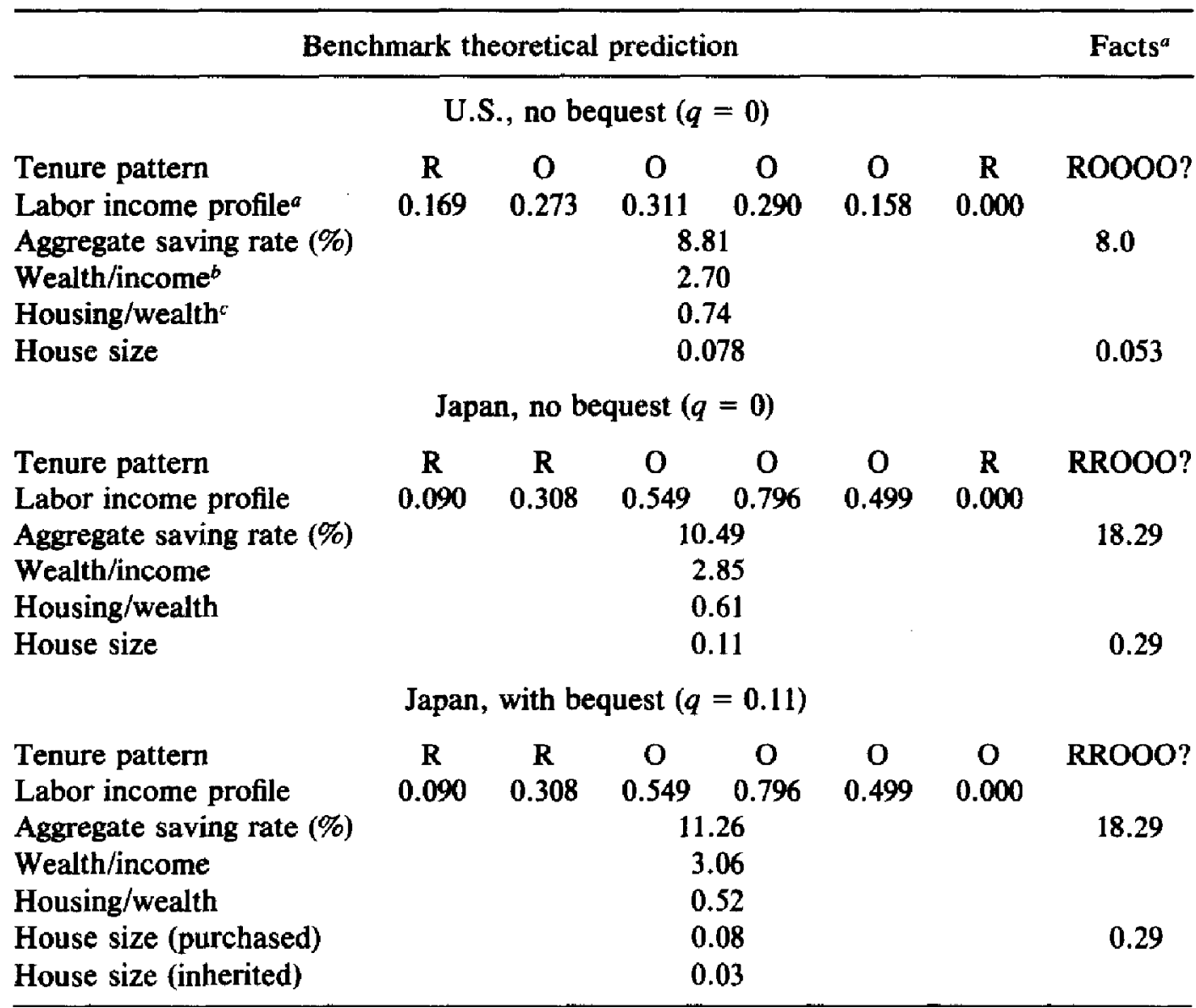

a The labor income and saving rate profile is a lifetime labor income stream of a typical agent in the model. The profiles are calculated as longitudinal predictions, while the aggregate saving rate is a cross-section prediction.

${ }^{b}$ Wealth is the sum of financial assets and housing equity (value minus outstanding mortgage). Income is measured on an annual basis.

c The value of land is not included in either housing or wealth. The observed ratio of the value of the housing/wealth ratio is indeed higher in the United States than in Japan, as suggested by this simulation table. However, the value of land is much higher in Japan than in the United States. See also footnote 2 in the text.

when he is 30 years old with a 30 -year mortgage. These predicted patterns match the stylized facts summarized in previous sections.

The saving rate predicted by the model is $8.81 \%$ for the United States and $10.49 \%$ for Japan. Hayashi (1986) calculates private saving rates for the two countries after correcting for the difference in statistical definitions. According to Hayashi's estimates, the average private saving rates for the United States and Japan during the 1970 s were 8.0 and $18.3 \%$, respectively. Thus the prediction for the United States is quite reflective 
of the stylized fact but the prediction for Japan falls short of the actual rate by 8 percentage points.

The model also shows that the housing stock share in national wealth is much lower in Japan than in the United States despite the high saving rate. We will investigate factors that contribute to the low housing stock in Japan by simulation experiments later.

The model overpredicts the housing size for the United States, while it underpredicts the housing size for Japan. The discrepancy might be a signal that our utility function is misspecified. However, without the Cobb-Douglas assumption, the explicit form of solution is hard to obtain.

In the rest of this section, simulations with respect to the bequest motive, down-payment ratio, and the income growth rate will be conducted to evaluate the impact of changes in the financial institutions and economic environment on the housing market. ${ }^{7}$

\subsection{Bequest Motive in Japan}

One reason that the benchmark simulation underpredicts the Japanese saving rate is its failure to consider the bequest motive. ${ }^{8}$ If the oldest generation does not consume all its wealth, especially the proceeds from the house sale which becomes available at the beginning of the last period of the life cycle, then the aggregate saving rate would increase.

Without a bequest motive, the assumption that the individual sells the house at the beginning of the sixth period is not critical. However, with a bequest motive, the assumption becomes problematic. In Japan houses are often used as a vehicle for making a bequest, partly because of the tax advantage of bequeathing housing relative to financial assets. ${ }^{9}$

How large a bequest motive is required to generate a saving rate comparable to the actual rate? Table II (the third panel) shows the saving rate that results when the representative individual is required to bequeath housing of 0.2 , the house size which would be owned without a bequest motive (i.e., the benchmark case). The experiment is conducted on the

${ }^{7}$ We also investigated how robust the benchmark result is with respect to the pride-ofownership parameter, about which we do not have strong confidence. The tenure choice pattern and the saving rate predicted by the model were found to be not sensitive with respect to this parameter for either country.

${ }^{8}$ One of the reasons that the bequest motive is more important in Japan is the popularity of the extended family relationship. If parents expect to live with (and/or to be taken care of by) children, they might leave bequests in return.

${ }^{9}$ It is well known in Japan that the assessed value of real estate for inheritance is about one-half or one-third of the market value, while financial assets are assessed at the full market value. Therefore, a rational agent who plans to bequeath should do so in the form of real assets, ceteris paribus. This tax treatment works against dissaving of housing among the elderly in Japan. 
assumption that the household may purchase additional housing (add rooms) to supplement the bequest, and that the housing is held through the last period of life. In addition, the house is assumed to be bequeathed without debt against it.

The calculated saving rate with the bequest assumption of house size 0.2 is $11.18 \%$. Hence, the bequest motive increases the aggregate saving rate by 0.7 percentage point. Modeling this type of bequest does increase the aggregate saving rate, but the magnitude of the increase is small compared to the U.S.-Japan gap. This is because adding the bequest motive has two offsetting effects on saving. On the one hand, the person is not presumed to consume the proceeds of the house sale at the end of the fifth period. This increases the aggregate saving rate. On the other hand, when a housing bequest is expected in the third period, less saving is the first and second periods for the down payment is required.

In order to assess the sensitivity of the saving rate to the housing bequest, experiments with different size of housing bequest were conducted. A bequest house size of 0.054 yields an aggregate saving rate of $9.88 \%$, while a bequest house size of 0.163 yields an aggregate saving rate of $12.60 \%$. These simulation exercises suggest that the saving rate is somewhat sensitive with respect to this form of bequest motive, but cannot generate large changes in saving.

\subsection{Non-steady State}

One of the key assumptions in the benchmark case is that the economy is in a steady state. The growth rates of population and real income and a (normalized) labor-income profile were assumed to have stayed the same for all generations. This assumption is particularly troublesome in the case of Japan. Economic growth in Japan from 1950 to 1973 averaged around $10 \%$ a year, about twice as much as the growth rate assumed for the Japanese benchmark in the preceding section. It is well known that in a standard life-cycle model where the young are savers, a higher growth rate implies a higher saving rate. This is because the older generation of dissavers has a much smaller "economic weight" than the younger generation of savers. Even if the rate of trend growth is halved as it was in Japan after the first oil crisis, the economic weight of older generations is very small due to rapid economic growth in the past. Hence, it is not surprising that the benchmark model underpredicted the actual saving rate.

We then simulate the life-cycle saving-consumption pattern for each generation using the actual (time-varying) economic growth rates in the past and the benchmark rate for the future. The income pattern for each generation is calculated using the actual 10-year economic growth rate and the cross-section age-income profile at 1980. The interest rate is 
assumed to be contant over time. For example, a generation born in 1920 is assumed to have had perfect foresight, and to have known the life-cycle income path from 1920 to 1980 . (We, however, are assuming the housetenure decision to be RROOOR in this exercise.) The same procedure is applied to other generations. The aggregate saving rates at year $t, t=$ $1980, \ldots .2030$, are calculated by aggregating the income and saving for different generations, who are at the different stages of the life cycle with time-varying income growth rates. We use the actual population weights of different generations for the past and the projected population weights for the future.

Table III shows the simulated Japanese saving rate from 1980 to 2030. In 1980 , the rate is 16.12 , significantly higher than that of the (steadystate) benchmark case and approaching the actual saving rate of 18.29. This is as expected due to rapid economic growth in the 1950s and 1960s, which implies that those who are dissaving have a small weight in the Japanese economy of 1980 . The assumption of steady economic growth

TABLE III

Simulated Japanese Saving Rate, 1980-2030, in Non-Steady State

\begin{tabular}{lcccccc}
\hline & 1980 & 1990 & 2000 & 2010 & 2020 & 2030 \\
\hline Actual saving rate & 18.29 & na & na & na & na & na \\
Projected saving rate & 16.12 & 14.97 & 15.03 & 12.96 & 8.09 & 5.27 \\
Wealth/income & 2.3 & 2.8 & 3.3 & 3.7 & 3.7 & 4.3 \\
Housing/wealth & 0.73 & 0.67 & 0.53 & 0.45 & 0.47 & 0.41
\end{tabular}

Assumed parameters: Economic growth rates (\%) for each decade

$\begin{array}{llll}1900-1910: & 27.03 & 1940-1950: & -29.23 \\ 1910-1920: & 44.44 & 1950-1960: & 130.67 \\ 1920-1930: & 22.94 & 1960-1970: & 170.99 \\ 1930-1940: & 64.20 & 1980-1990 \text { and on: } 41.90\end{array}$

Population weights

\begin{tabular}{lcccccc} 
& \multicolumn{7}{c}{ Age } \\
\cline { 2 - 7 } & $20-29$ & $30-39$ & $40-49$ & $50-59$ & $60-69$ & $70-79$ \\
\hline 1960 & .212 & .252 & .206 & .161 & .106 & .063 \\
1970 & .286 & .241 & .192 & .134 & .097 & .049 \\
1980 & .298 & .245 & .178 & .142 & .092 & .045 \\
1990 & .194 & .194 & .225 & .181 & .133 & .072 \\
2000 & .195 & .181 & .177 & .201 & .153 & .093 \\
2010 & .177 & .192 & .175 & .167 & .178 & .112 \\
2020 & .177 & .178 & .189 & .169 & .152 & .134 \\
\hline
\end{tabular}

Source. Various years of Census and "Projection of the Japanese Population" by Jinkou Mondai Kenkyuukai. 
from 1980 on assures that the aggregate saving rate converges to the stead-state benchmark in the future. Our simulation shows that the saving rate will drop by 1 (percentage) point in 10 years, 3 points in 30 years, and 8 points in 40 years. The simulated Japanese saving rate will become very much like the American one in a half-century.

We conclude this section with three observations. First, with a nonsteady-state assumption, the simulated saving rate is much higher than the benchmark. However, the model still underpredicts the actual saving rate. Second, the saving rate is projected to decline in the future as the lower growth rate persists. These results are consistent with the theoretical prediction that the saving rate is very sensitive to the economic growth rate.

\subsection{Simulations with Respect to Down-Payment Ratios}

We next investigate how much difference the down-payment constraint makes in the housing tenure choice and the saving rate. Of course, the higher the down-payment ratio, the more distortion in the lifetime consumption pattern required to finance the same amount of owned housing.

Table IV shows how sensitive the housing tenure pattern is with respect

TABLE IV

Effects of Changes in Down-Payment Ratio

\begin{tabular}{|c|c|c|c|c|c|}
\hline & \multicolumn{5}{|c|}{ Down-payment ratio } \\
\hline & $15 \%$ & $25 \%$ & $30 \%$ & $35 \%$ & $40 \%$ \\
\hline \multicolumn{6}{|c|}{ United States, no bequest } \\
\hline$T$ & ROOOOR & ROOOOR & ROOOOR & ROOOOR & ROOOOR \\
\hline$S(\%)$ & 8.29 & 8.81 & 9.03 & 9.22 & 8.21 \\
\hline$W / I$ & 3.4 & 2.7 & 2.7 & 2.8 & 2.8 \\
\hline \multirow[t]{2}{*}{$H / W$} & 0.91 & 0.74 & 0.70 & 0.66 & 0.84 \\
\hline & \multicolumn{5}{|c|}{ Japan, no bequest } \\
\hline$T$ & RROOOR & RROOOR & RROOOR & RROOOR & RROOOR \\
\hline$S(\%)$ & 9.37 & 9.98 & 10.25 & 10.49 & 10.71 \\
\hline$W / I$ & 2.5 & 2.7 & 2.8 & 2.9 & 2.9 \\
\hline \multirow[t]{2}{*}{$H / W$} & 0.76 & 0.67 & 0.64 & 0.61 & 0.58 \\
\hline & \multicolumn{5}{|c|}{ Japan, no bequest, non-stcady state, 1980} \\
\hline$T$ & RROOOR & RROOOR & RROOOR & RROOOR & RROOOR \\
\hline$S(\mathscr{F})$ & 14.30 & 15.03 & 15.44 & 16.12 & 16.44 \\
\hline$W / I$ & 2.1 & 2.2 & 2.3 & 2.3 & 2.3 \\
\hline$H / W$ & 0.84 & 0.79 & 0.75 & 0.73 & 0.72 \\
\hline
\end{tabular}

Note. Cases highlighted in boxes represent the stylized values of the down-payment ratio in each country. 
to changes in the down-payment ratio. The U.S. housing tenure pattern would look like Japan's (housing purchase postponed until the third period) if the down-payment requirement were raised to $40 \%$. In Japan, the tenure pattern currently observed in the United States would not emerge even at a down-payment ratio of $15 \%$. Therefore, although a change in the down-payment ratio could alter the tenure choice pattern, the change would have to be very large. The observed tenure pattern in each country is predicted for a wide range of the down-payment ratios around the respective benchmark cases.

Table IV also shows that the aggregate saving rate is positively related to the down-payment ratio. An increase of $10 \%$ in the down-payment ratio increases the saving rate by less than 1 percentage point in each country, given that the tenure choice pattern is not altered. The magnitude of the down-payment ratio effect is not as large as one might think, because there are two offsetting impacts from a higher down-payment ratio. First, higher saving is required for a given size of house. Second, a higher downpayment ratio causes a smaller house to be purchased given the tenure choice pattern. The simulation results show that the first effect is only barely dominant.

Table IV also shows how the relative share of housing in national wealth would be affected if the down-payment ratio were changed. When the down-payment ratio in Japan becomes as low as $15 \%$ the housing share in national wealth becomes comparable to that in the United States.

In sum, this model suggests that the difference in the required downpayment ratios in the United States and Japan is not a major source of the difference in the saving rate. However, a large enough decline in the required down-payment ratio in Japan would induce a saving rate and lifecycle tenure pattern similar to those of the United States. In Japan, casual evidence suggests that the down-payment ratio was higher in the 1950s and 1960s, so that it could have been a stronger factor for a high saving rate in the past.

\subsection{Simulations with Respect to the Income Growth Rate}

First, note that the benchmark model is constructed in such a way that the slope of the earning profile for one generation is positively related to the expected income growth over generations. This feature comes from the fact that the observed cross-section data must be converted into a steady-state lifetime earning profile. Thus, in the following experiments using the steady state, faster growth implies a steeper earning profile.

Results of the sensitivity analysis with respect to the income growth rate are summarized as follows. It is well known that the aggregate saving rate increases, if the steady-state growth rate of labor income over generations increases so long as the younger generations are the savers. This is 
confirmed in our simulation model ${ }^{10}$ In fact, if the Japanese growth rate is only $10 \%$, the growth rate of the United States, then the predicted steadystate Japanese saving rate (without a bequest motive) would be $6.62 \%$, which is even below the current U.S. saving rate simulated in the model. The tenure choice of the Japanese case is not affected by the change in the income growth rate.

However, in the United States the renting period is extended by 10 more years if income grows at the Japanese rate, i.e., the age earning profile becomes steeper. The steeper earning profile implies that the utility penalty imposed by the distortion caused by saving toward down payments becomes more burdensome. The saving rate is increased to 8.67\%, which is far short of the actual and less even than the simulated Japanese saving rate.

\subsection{Simulations of Tax Reforms}

Our final simulation experiments concern changes in the tax laws which determine incentives for saving and borrowing. As was discussed in the Introduction, the tax incentives affecting saving and borrowing in the two countries are quite different.

The United States and Japan (prior to the change on April 1, 1988) differ in two aspects: the tax exemption of the interest income from saving in Japan only and the tax deductibility of mortgage interest payments in the United States only. For each aspect, the simulation will be conducted for hypothetical situations given all other parameters.

Our model gives simulation results, shown in Table $\mathrm{V}$, for a full range of interesting policy questions both in the United States and in Japan: How much would the U.S. low saving rate be stimulated if interest income becomes tax exempt? How would tenure choice and average housing size be affected if mortgage payments become nondeductible? What are the combined effects of tax-exempt saving and the nondeductible interest payments? The last question can be paraphrased as follows. If the United States switched to the Japanese tax system, what would happen to the saving rate and housing tenure pattern?

The effect of allowing tax-exempt saving in the United States is shown in the (Yes-Yes) column in Table $\mathrm{V}$. The simulated aggregate saving rate increases by $1.5 \%$, without changing the tenure choice pattern. The increase is not insignificant, if one is interested in raising the saving rate.

${ }^{10}$ However, Hayashi (1986) obtained an opposite result in a model where there is no liquidity or down-payment constraint. This is due to the fact that the steep labor income profile causes the very young to be borrowers. 
TABLE $\mathrm{V}$

Effects of Tax Reforms on the Saving Rate

U.S.: Using U.S. parameters and income profiles

\begin{tabular}{|c|c|c|c|c|}
\hline & \multicolumn{4}{|c|}{ Tax treatment } \\
\hline & No. 1 & $\begin{array}{c}\text { No. } 2 \\
\left(\text { Japan }^{a}\right)\end{array}$ & $\begin{array}{c}\text { No. } 3 \\
\text { (U.S. status quo) }\end{array}$ & No. 4 \\
\hline \multicolumn{4}{|l|}{ Interest income tax } & No \\
\hline $\begin{array}{l}\text { Interest payments tax } \\
\text { deductible? }\end{array}$ & Yes & No & Yes & No \\
\hline $\begin{array}{l}\text { Tenure choice } \\
\text { Aggregate saving }(\%)\end{array}$ & $\begin{array}{c}\text { ROOOOR } \\
10.27\end{array}$ & $\begin{array}{c}\text { ROOOOR } \\
9.94\end{array}$ & $\begin{array}{l}\text { ROOOOR } \\
8.81\end{array}$ & $\begin{array}{c}\text { ROOOOR } \\
8.43\end{array}$ \\
\hline \multicolumn{5}{|c|}{$\begin{array}{l}\text { Japan: No bequest, steady state, using Japanese parameters } \\
\text { and income profiles }\end{array}$} \\
\hline & No. 1 & $\begin{array}{l}\text { No. } 2 \\
\left.\text { (Japan status quo }{ }^{a}\right)\end{array}$ & $\begin{array}{l}\text { No. } 3 \\
\text { (U.S.) }\end{array}$ & No. 4 \\
\hline $\begin{array}{l}\text { Interest income tax } \\
\text { exempt? }\end{array}$ & Yes & Yes & No & No \\
\hline $\begin{array}{l}\text { Interest payments tax } \\
\text { deductible? }\end{array}$ & Yes & No & Yes & No \\
\hline $\begin{array}{l}\text { Tenure choice } \\
\text { Aggregate saving (\%) }\end{array}$ & $\begin{array}{c}\text { RROOOR } \\
10.83\end{array}$ & $\begin{array}{c}\text { RROOOR } \\
10.49\end{array}$ & $\begin{array}{l}\text { RRROOR } \\
7.01\end{array}$ & $\begin{array}{c}\text { RRROOR } \\
\quad 6.98\end{array}$ \\
\hline \multicolumn{5}{|c|}{$\begin{array}{c}\text { Japan: No bequest, non-steady state, } 1980 \text {, using Japanese parameters } \\
\text { and income profiles }\end{array}$} \\
\hline & No. 1 & $\begin{array}{l}\text { No. } 2 \\
\text { (Japan status quo }\end{array}$ & $\begin{array}{l}\text { No. } 3 \\
\text { (U.S.) }\end{array}$ & No. 4 \\
\hline \multirow{2}{*}{$\begin{array}{l}\text { Interest income tax } \\
\text { exempt? } \\
\text { Interest payments tax } \\
\text { deductible? }\end{array}$} & Yes & Yes & No & No \\
\hline & Yes & No & Yes & No \\
\hline $\begin{array}{l}\text { Tenure choice } \\
\text { Aggregate saving (\%) }\end{array}$ & $\begin{array}{c}\text { RROOOR } \\
16.51\end{array}$ & $\begin{array}{l}\text { RROOOR } \\
16.12\end{array}$ & $\begin{array}{l}\text { RRROOR } \\
9.86\end{array}$ & $\begin{array}{c}\text { RRROOR } \\
9.84\end{array}$ \\
\hline
\end{tabular}

${ }^{a}$ Prior to April 1, 1988.

However, even with an increase of $1.5 \%$, the gap in the saving rates of the two countries would remain large. ${ }^{11}$

1 Note that the model is not general equilibrium in nature, so that the interest rate is held constant when tax policy and the capital stock are changed. Introducing general equilibrium considerations would presumably dampen the predicted changes in the saving rate. 
Suppose next that mortgage interest payments become not tax deductible in the United States. This is the case indicated by (No-No) in Table V. The model predicts that the saving rate would be reduced by a small amount, less than $0.5 \%$. This result contrasts with the usual presumption that the tax deductibility of interest payments reduces the saving rate because it makes the cost of borrowing less. However, since buying a house does not represent dissaving (rather a change in portfolio) the aggregate saving rate in fact decreases when the cost of borrowing to buy a house rises, due to the decreased saving required to purchase the nowoptimal smaller house. ${ }^{12}$

Suppose that the United States switched to the (former) Japanese tax system so that interest income is tax exempt and mortgage interest payments are not tax deductible. In this case the model predicts that the saving rate would increase by 1 percentage point.

Simulation experiments are then conducted for the Japanese case in order to answer questions symmetric to the U.S. experiments: How much would the high Japanese saving rate be reduced if the tax-exempt saving system is abolished? Would the typical Japanese tenure choice pattern be affected by the favorable tax treatment on mortgage payments, as in the United States? What would be the combined effect, i.e., if Japan switched to the U.S. tax system?

The first question is quite relevant since the Japanese government has just abolished the tax-exempt status of the "maru-yu" accounts. The second question is also relevant, since adopting a more favorable tax treatment of mortgage payments is always proposed when housing problems are discussed in Japan. The presumption is that the housing stock is one area where Japan lags behind the United States.

The model predicts that abolition of the "maru-yu" accounts in Japan causes a drop in the steady-state saving rate by 3 to 4 percentage points. The housing tenure pattern would also change, so that the Japanese would rent 10 more years before purchasing a house. The large change in the saving rate comes from the change in tenure pattern. Since a house is not owned until the beginning of the fourth period, the distortion in saving for the down-payment in the first half of the working life becomes much less.

If Japan were to introduce tax deductibility of mortgage interest payments, then the model predicts a very slight increase in the aggregate

${ }^{12}$ Remember that a liquidity constraint equivalent to a ban on borrowing in excess of housing capital is imposed in the model. Therefore, tax incentives for borrowing will not increase the demand for the composite consumption good during the first period, when the liquidity constraint is binding. If our focus is shifted from the down-payment constraint to borrowing constraints for consumption, we would investigate the effect of eliminating the tax deductibility of interest payments on consumer loans. In this case elimination could raise the saving rate. 
saving rate, without changing the tenure choice pattern. If Japan adopts the U.S. tax system with respect to interest income and interest payments, then the model predicts a drop in the saving rate of 3.5 percentage points.

The third panel of Table $\mathrm{V}$ shows what the non-steady-state aggregate saving rate would be if the hypothetical tax regime had been in place during the postwar period. In 1980, the saving rate would have been lower by 6 percentage points had the "maru-yu" not been available.

The tax-exempt status of interest income has a stronger impact on the saving rate than the tax deductibility of mortgage interest payments in both countries. The latter does not change the aggregate saving rate more than 50 basis points in any case in either country. Simulation results indicate that differences in the tax incentives between the two countries explain only 3 to 4 percentage points of the gap of 10 percentage points between the saving rates of the two countries.

\section{Concluding Remarks}

We constructed a simulation model in order to evaluate the effects of changes in housing finance institutions and tax policy on housing tenure patterns and the aggregate private saving rate. Simulation results suggest that the factors do not offer a complete explanation of the large gap between the saving rates of the two countries. There are two reasons behind this conclusion. First, although the typical down-payment ratio varies across the two countries, the variation is not sufficient to affect the aggregate saving rate by a significant amount. Second, tax reform experiments indicate that only 1 to 4 percentage points of the 10-point gap are attributable to the difference in the tax incentives.

The model, in particular the one with non-steady-state assumptions, suggests that the difference in the income growth rate over generations can explain a greater amount of the saving rate gap. Given the difference in the income growth rates, we suspect also that the Japanese have a stronger bequest motive, perhaps due to their extended family relationships. Finally, our simulations suggest that the Japanese saving rate will drop significantly in the long run, as the economy moves to a new lowgrowth steady state that subjects interest income to taxation.

As is true for all numerical simulation analyses, the quantitative results presented here depend on our choices concerning the specification of the model. Several aspects of this specification are especially worthy of note. The use of a log-linear utility function implies an intertemporal and intratemporal elasticity of substitution equal to one. This is likely to overstate the actual degree of substitutability, and thus understate the welfare cost 
of a given distortion in saving/consumption patterns. For example, with less intertemporal substitutability, an increase in the required down-payment ratio is more likely to cause a household to postpone and reduce the size of a housing purchase, rather than have to reduce consumption early in the life cycle.

The six-period formulation is also rather arbitrary and allows the consideration of only large discrete changes in the lifetime tenure pattern. A model with more peirods would be able to treat the more continuous adjustment of tenure patterns in response to a change in the economic environment. The cost of implementing such a model is, of course, the increased computational expense.

Finally, an improved model would more carefully treat the bequest motive and, in general, transactions between generations. Differences in these transactions between the United States and Japan potentially play a large role in the determination of housing decisions and saving decisions as well as in the effect of tax policy and other institutional arrangements on these decisions.

In spite of these qualifications, we believe that this analysis represents a valuable contribution to the quantitative analysis of the interaction of housing market institutions, tax policy, and saving behavior in the United States and Japan. It has demonstrated the importance of treating demand for housing and saving behavior simultaneously within the context of a dynamic model.

\section{REFERENCES}

BANK of JAPAN (1986). "Annual Economic Statistics."

Bernhetm, B. D., Shletfer, A., And Summers, L. (1985). The strategic bequest motive, J. Polit. Econo. 93, 1045-1076.

Federal Home Loan Bank Board (1982). "Savings and Home Finance Source Book."

HAYASHI, F. (1986). Why is Japan's saving rate so apparently high? in "NBER Macroeconomic Annual, 1986," MIT Press, Cambridge, MA.

Office of Prime Minister (1982). "Family Saving Survey."

Ministry of Construction (various years). "Results of Survey on Financing Private Housing."

SLEMrod, J. (1982). Down-payment constraints: Tax policy effects in a growing economy with rental and owner-occupied housing, Public Finance Quart. 10, 193-217.

U.S. Department of Commerce (1981). "Money Income of Households, Families, and Persons in the United States: 1980."

U.S. Department of Labor (1985). "Handbook of Labor Statistics."

U.S. Department of Housing and Urban Development (1979). "Statistical Yearbook." 